\title{
Agriculture Based Recommender System using IoT - A Research
}

\author{
Manoj Athreya A, Hrithik Gowda S, S Madhu, Ravikumar V
}

\begin{abstract}
In today's world, IoT (Internet of Things) plays an important role in human life simply by allowing objects to be sensed or remotely controlled through other existing networks. Traditional farming methods with some recommendations will save time and effort. In this paper, we have planned to use technologies such as IoT, Machine Learning and Cloud computing to recommend to farmers the type of crop to be grown on the basis of available resources, climate, rainfall, temperature, market prices, area of land, past crop yield and other parameters, thereby reducing the effort and time required for different agricultural processes. In considering the above parameters, it is recommended that farmers grow and the type of pesticides and water supply be used from time to time. The system can help farmers produce suitable crops. As a result, they can improve their lifestyles and help society more. In this paper, we present an attempt to predict the yield and price of crops that a farmer can obtain from his land by analyzing past data patterns. It gives them an overview of the recommendation to grow the plant until the crop is sold. Therefore, provide a comprehensive guide to help farmers in their agricultural work.
\end{abstract}

Keywords: Agriculture, Recommender system, Machine Learning, IoT.

\section{INTRODUCTION}

The days are gone when the planet relies heavily on agriculture and agriculture currently depends on the planet. Agriculture is something people have started to dazzle about, forgetting that it is what keeps America alive. However, some tireless, choleric farmers still live on farming. However, there is also corruption, which is growing considerably today. The main motive of the Department of Agricultural Promotion \& Agricultural Business is to honestly have a good value for the United Nations farming community agency behind this competitive promotion situation, and the mission of achieving fair value is to create the current act and rules that are robust and more practical by implementing new technologies and techniques aimed at achieving fair value. The main purpose of establishing a regulated market is to eliminate unhealthy trade follow - up, to reduce market expenditure and to provide farmers with honest costs. Many initiatives are taken to promote agriculture so that rural

Revised Version Manuscript Received on August 19, 2019. Engineering,Vidyavardhaka College of Engineering, Mysuru, Karnataka India.(email: manoj2375@gmail.com)

Hrithik Gowda S, Department of Computer Science and Engineering,Vidyavardhaka College of Engineering, Mysuru, Karnataka India.

S Madhu, Department of Computer Science and Engineering,Vidyavardhaka College of Engineering, Mysuru, Karnataka India

Ravikumar V, Department of Computer Science and Engineering,Vidyavardhaka College of Engineering, Mysuru, Karnataka India.
Manoj Athreya A,Department of Computer Science and

economic development is promoted and maintained [1]

A recommendation system can be defined as a software

class that helps users to obtain the most appropriate products based on their preferences, needs or tastes [2]. It applies knowledge discovery techniques to the problem of personalized information, products or services recommendations during a live interaction between e-commerce, social media, and content-based websites. It can also be used effectively in the agricultural sectors with its immense power [2].

Today, we are in a world of smart devices and we use a network called the Internet of Things (IoT) to connect these devices. In today's world, IoT is evolving to a greater extent so that around 50 billion objects will be connected to the

Internet in 2020 [3]. IoT can be seen from speakers to home automation to smart doors and smart TV 's in various places. Each device can be connected, interacted and connected using other technologies such as wireless sensor networks, cloud computing, radio frequency identification or any other means [3]. In order to benefit agriculture from new opportunities for global market access, the country's internal agricultural marketing system must also be integrated and strengthened. In particular, the market system must be revitalized to [1]:

a) provide incentives for farmers to produce more;

b) transmit to producers the changing needs of buyers to enable production planning;

c) promote true competition between market players and

d) increase farmers' share of the ultimate price of their agricultural products.

Agriculture is our country's backbone. Although industry and other sectors have made India a diverse country, the majority of the population is still dependent on farm products. Many authors have presented their work with IoT in the area of intelligent agriculture work.

\section{RELATED WORKS}

Kanaga Subha Raja et al., [1] proposed a recommendation system based on rainfall, temperature, and other area parameters and suggesting the right crops. Based on crop yield and current market price, it is recommended that farmers obtain high yields and profits. Mokkaram and Arefin [2] has used an algorithm called Upazila Selection and uses the current seasonal detection for the harvest recommendation. It calculates on the basis of agro-climatic data and an agro-cultural background to recommend correct

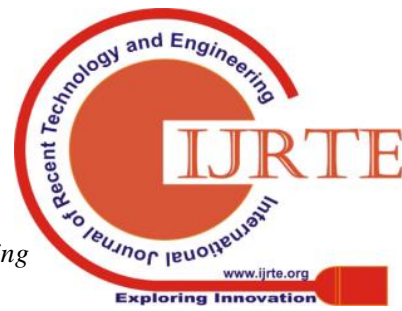


harvests at the right season.

Pudumalar et al., [3] used the data set comprising the attributes of the soil and other test results for consideration and used precision farming techniques to increase productivity and profitability. Shampa and Aseem [4] have made recommendations based on the available weather data and climate conditions. They used the Hidden Markov model to represent the weather and predict advice. Their weather analysis demonstrates a much-improved recommendation system.

Navya Sri [5] have used scalable graph-based collaborative filtering recommendation algorithm, unlike central recommender system which depicts the correct representation using the graph and another picture format. This enhances the accuracy and coverage area. Takashi Okayasu et al., [6] described their use of algorithm and devices for affordable field environmental monitoring and plant growth measurement system for smart agriculture. The sensors are used to measure plant height, leaf color, and other characteristics.

Zhao and Bai [7] have used IoT technology in conjunction with the remote monitoring system, the main objective of which is to collect and alert the agricultural production environment in real time through SMS. This paper gave the farmers a better understanding of how to sow and take care of the products. Lai and Zeng [8] used technologies such as Big Data, IoT and cloud computing to improve the yield of crops. This model analyzes the sequence of crops, the next crop to be grown, fertilizer requirements, etc. This model facilitates the estimation of total production and fertilizer requirements per crop, as well as the control of the costs of agricultural products.

Ren and $\mathrm{Lu}$ [9] submitted a paper using a recommendation system based on humidity and humidity control that collects the data sets required from the geographical area to be grown and the type of fertilizer to be used. Increase the productivity of the crop. Mekala and palanisamy [10] used an algorithm to predict the growth rate of crops based on the resources provided, recommending the requirements to be supplied during the growth on the basis of the type of crop.

Vin Gia Nhi et al., [11] aims to include all the important factors for the successful production of crops. It comprises all major sensors and implements IoT technology for seed recognition with image processing. PI for raspberry is used. The sensor data, which was easily accessed by the Android app and the experiment, was a success. Feng et al., [12] presented recommendations on the application and improvement of the intelligence of agricultural information and the IoT prior algorithm for the use of sensors to collect information and process data and make recommendations based on them.

\section{COMPARISON OF DIFFERENT RECOMMENDER SYSTEM FOR AGRICULTURE USING IoT \& RESULTS}

Table 1 gives us a picturesque idea of the methods used by various smart agriculture researchers with IoT. It also gives the list of recommendations that we thought might in future have been implemented in the system.

Table 1. Comparison of different recommender System for agriculture by using IoT

\begin{tabular}{|c|c|c|c|c|c|c|}
\hline $\begin{array}{l}\text { Ref. } \\
\text { No }\end{array}$ & Objective & $\begin{array}{l}\text { Concept } \\
\text { Used }\end{array}$ & $\begin{array}{l}\text { Results/ } \\
\text { Outcome }\end{array}$ & $\begin{array}{l}\text { Advan } \\
\text { tage }\end{array}$ & Disadvantage & $\begin{array}{l}\text { Recommenda } \\
\text { tion }\end{array}$ \\
\hline$\# 1$ & $\begin{array}{l}\text { In this paper } \\
\text { based on climate } \\
\text { yield and to the } \\
\text { farmer about } \\
\text { rainfall and } \\
\text { temperature. }\end{array}$ & IoT & $\begin{array}{c}\text { By } \\
\text { applying } \\
\text { this } \\
\text { technique, } \\
\text { the farmers } \\
\text { will be } \\
\text { benefited } \\
\text { and } \\
\text { improveme } \\
\text { nt in } \\
\text { yielding of } \\
\text { crops. }\end{array}$ & $\begin{array}{c}\text { It } \\
\text { increases } \\
\text { the crop } \\
\text { rate by } \\
3 \% .\end{array}$ & $\begin{array}{l}\text { More sensors can } \\
\text { be used in order to } \\
\text { have a complete } \\
\text { summary of the crop } \\
\text { health, produce and } \\
\text { the soil conditions as } \\
\text { well. Battery energy } \\
\text { consumption can be } \\
\text { more as for every } \\
\text { node, the sensors need } \\
\text { the batteries. }\end{array}$ & $\begin{array}{l}\text { Solid ph. can } \\
\text { be implemented } \\
\text { here. }\end{array}$ \\
\hline$\# 2$ & $\begin{array}{c}\text { In this users } \\
\text { location and } \\
\text { different } \\
\text { agro-ecological } \\
\text { and agro climatic } \\
\text { is taken and } \\
\text { calculated using } \\
\text { the Pearson } \\
\text { correlation } \\
\text { similarity } \\
\text { technique. }\end{array}$ & IoT & $\begin{array}{c}\text { In this } \\
\text { paper based } \\
\text { on the } \\
\text { algorithm } \\
\text { and data } \\
\text { sets } \\
\text { collected } \\
\text { recommend } \\
\text { ation of } \\
\text { crops are } \\
\text { made at } \\
\text { upazil level. }\end{array}$ & $\begin{array}{c}\text { It } \\
\text { increases } \\
\text { the } \\
\text { productio } \\
\text { n rate by } \\
7 \%\end{array}$ & $\begin{array}{l}\text { The use of an } \\
\text { expert system and IoT } \\
\text { is an excellent way to } \\
\text { improve the crop rate. }\end{array}$ & $\begin{array}{c}\text { The use of } \\
\text { advanced } \\
\text { technologies like } \\
\text { physiographic } \\
\text { mechanism can } \\
\text { be used here. }\end{array}$ \\
\hline
\end{tabular}




\begin{tabular}{|c|c|c|c|c|c|c|}
\hline$\# 3$ & $\begin{array}{c}\text { Precision } \\
\text { agriculture which } \\
\text { is the modern } \\
\text { farming } \\
\text { techniques the } \\
\text { approach used } \\
\text { here. }\end{array}$ & $\begin{array}{c}\text { K nearest } \\
\text { Neighbors and } \\
\text { naïve random } \\
\text { tree technique }\end{array}$ & $\begin{array}{c}\text { In this } \\
\text { technique, it } \\
\text { was more } \\
\text { productive } \\
\text { and more } \\
\text { profit and it } \\
\text { helped } \\
\text { many to } \\
\text { plant the } \\
\text { right crop at } \\
\text { the right } \\
\text { time. }\end{array}$ & $\begin{array}{l}\text { The } \\
\text { use of an } \\
\text { expert } \\
\text { system } \\
\text { and IoT is } \\
\text { an } \\
\text { excellent } \\
\text { way to } \\
\text { improve } \\
\text { the crop } \\
\text { rate. }\end{array}$ & $\begin{array}{l}\text { The expert system } \\
\text { does tell about the } \\
\text { herbicide and } \\
\text { pesticide } \\
\text { recommendation } \\
\text { depending on the } \\
\text { disease but the use of a } \\
\text { camera or an image } \\
\text { capturing device is } \\
\text { used in their paper. } \\
\text { Also, battery } \\
\text { consumption can be } \\
\text { high. }\end{array}$ & $\begin{array}{l}\text { Use of the } \\
\text { technologies like } \\
\text { the camera, ph. } \\
\text { rate, solar we can } \\
\text { optimize the crop } \\
\text { rate. }\end{array}$ \\
\hline$\# 4$ & $\begin{array}{l}\text { Recommendat } \\
\text { ion based on } \\
\text { weather data of } \\
\text { the location and } \\
\text { the interest of } \\
\text { people to such } \\
\text { conditions from } \\
\text { past }\end{array}$ & $\begin{array}{r}\text { IoT, hidden } \\
\text { Markov model }\end{array}$ & $\begin{array}{l}\text { It shows } \\
\text { that weather } \\
\text { context } \\
\text { greatly } \\
\text { enhances } \\
\text { the } \\
\text { recommend } \\
\text { ed system. }\end{array}$ & $\begin{array}{c}\text { It } \\
\text { increases } \\
\text { the } \\
\text { accuracy } \\
\text { of the } \\
\text { weather } \\
\text { data }\end{array}$ & $\begin{array}{l}\text { Li-Fi being quite } \\
\text { advanced takes time to } \\
\text { be set up in } \\
\text { developing countries } \\
\text { but once done, it can } \\
\text { be a boon for the } \\
\text { sector and this idea } \\
\text { can be implemented. } \\
\text { Moreover, cattle } \\
\text { sensors used are risky } \\
\text { when the animals may } \\
\text { fidget with it and the } \\
\text { sensors can get } \\
\text { damaged. It is not } \\
\text { even cost effective as } \\
\text { each animal needs a } \\
\text { separate sensor. }\end{array}$ & $\begin{array}{l}\text { We can use } \\
\text { lifi technology to } \\
\text { improve the } \\
\text { accuracy of the } \\
\text { problem. }\end{array}$ \\
\hline$\# 5$ & $\begin{array}{l}\text { Recommendat } \\
\text { ion based on trust } \\
\text { enhanced factor } \\
\text { and graphic } \\
\text { analysis }\end{array}$ & IoT & $\begin{array}{c}\text { The } \\
\text { inclusion of } \\
\text { trust into } \\
\text { the RS } \\
\text { increases } \\
\text { both } \\
\text { accuracy } \\
\text { and } \\
\text { coverage. }\end{array}$ & $\begin{array}{c}\text { It } \\
\text { increases } \\
\text { IOT } \\
\text { network } \\
\text { accuracy. }\end{array}$ & $\begin{array}{c}\text { The main } \\
\text { disadvantage is that in } \\
\text { case of large fields, } \\
\text { the playhouses cannot } \\
\text { be used as it increases } \\
\text { the cost. The drip } \\
\text { irrigation setup cost } \\
\text { may also increase } \\
\text { when we consider a } \\
\text { large area. }\end{array}$ & $\begin{array}{c}\text { IOT } \\
\text { networking } \\
\text { should be } \\
\text { increased. }\end{array}$ \\
\hline \#6 & $\begin{array}{l}\text { Recommendat } \\
\text { ion based on trust } \\
\text { and regulation } \\
\text { model and } \\
\text { security }\end{array}$ & IoT & $\begin{array}{l}\text { It aims at } \\
\text { providing } \\
\text { protection } \\
\text { against IOT } \\
\text { attackers to } \\
\text { tackle } \\
\text { security } \\
\text { challenges }\end{array}$ & $\begin{array}{c}\text { It } \\
\text { improves } \\
\text { security. }\end{array}$ & $\begin{array}{c}\text { Security } \\
\text { challenges can be } \\
\text { faced. }\end{array}$ & $\begin{array}{l}\text { Security } \\
\text { should be } \\
\text { increased. }\end{array}$ \\
\hline$\# 7$ & $\begin{array}{l}\text { This paper is } \\
\text { based on a } \\
\text { recommended } \\
\text { system for the } \\
\text { agriculture } \\
\text { information } \\
\text { personalization } \\
\text { based on user } \\
\text { clustering }\end{array}$ & $\begin{array}{r}\text { IoT, data } \\
\text { mining, data } \\
\text { warehousing }\end{array}$ & $\begin{array}{c}\text { The } \\
\text { framework } \\
\text { drastically } \\
\text { increases } \\
\text { the system } \\
\text { for the } \\
\text { Agricult } \\
\text { ure } \\
\text { information } \\
\text { personalizat } \\
\text { ion }\end{array}$ & $\begin{array}{c}\text { It } \\
\text { improved } \\
\text { the } \\
\text { service } \\
\text { quality of } \\
\text { the } \\
\text { website }\end{array}$ & $\begin{array}{l}\text { The distance of } \\
\text { transmission is less } \\
\text { and it can cause } \\
\text { problems if the } \\
\text { connectivity is low. }\end{array}$ & $\begin{array}{l}\text { It has been } \\
\text { improved by } \\
\text { adding an } \\
\text { efficient and } \\
\text { optimized code }\end{array}$ \\
\hline \#8 & $\begin{array}{l}\text { Calculation on } \\
\text { energy state was } \\
\text { similarity baring } \\
\text { capacity. }\end{array}$ & $\begin{array}{l}\text { IoT, dynamic } \\
\text { tag, precision }\end{array}$ & $\begin{array}{c}\text { From } \\
\text { user } \\
\text { similarity } \\
\text { and service } \\
\text { resource } \\
\text { value the } \\
\text { following } \\
\text { theory was } \\
\text { validated }\end{array}$ & $\begin{array}{c}\text { It } \\
\text { improves } \\
\text { the } \\
\text { precessio } \\
\mathrm{n}\end{array}$ & $\begin{array}{l}\text { The ubimote } \\
\text { sensor board used can } \\
\text { result in failures and } \\
\text { this, in turn, may stop } \\
\text { the entire system from } \\
\text { working as this is the } \\
\text { one which gathers and } \\
\text { sends the information } \\
\text { to the farmers. }\end{array}$ & $\begin{array}{l}\text { We can use } \\
\text { improved } \\
\text { services. }\end{array}$ \\
\hline
\end{tabular}




\begin{tabular}{|c|c|c|c|c|c|c|}
\hline \#9 & $\begin{array}{l}\text { This paper is } \\
\text { based on the } \\
\text { design of } \\
\text { fertilization } \\
\text { recommendation } \\
\text { knowledge base } \\
\text { and applications }\end{array}$ & IoT, c++ & $\begin{array}{l}\text { The data } \\
\text { sensed by } \\
\text { the sensors } \\
\text { as easily } \\
\text { accessed } \\
\text { through the } \\
\text { Android } \\
\text { application } \\
\text { and the } \\
\text { experiment } \\
\text { was a } \\
\text { success. }\end{array}$ & $\begin{array}{c}\text { It } \\
\text { increases } \\
\text { the } \\
\text { fertilizati } \\
\text { on } \\
\text { efficiency } \\
\text {. }\end{array}$ & N/A & $\begin{array}{l}\text { The camera of } \\
\text { better quality can } \\
\text { be used, the } \\
\text { concept of master } \\
\text { node as specified } \\
\text { in paper 2, can be } \\
\text { used. Battery } \\
\text { efficiency can be } \\
\text { increased by } \\
\text { tuning the } \\
\text { microcontroller } \\
\text { to sleep when the } \\
\text { system is not in } \\
\text { use and by that } \\
\text { time, the batteries } \\
\text { can be charged } \\
\text { using solar. }\end{array}$ \\
\hline$\# 10$ & $\begin{array}{l}\text { Cognitive } \\
\text { approach for } \\
\text { recommended } \\
\text { system }\end{array}$ & $\begin{array}{c}\text { IoT, the } \\
\text { cognitive system } \\
\text { sensors }\end{array}$ & $\begin{array}{c}\text { The } \\
\text { framework } \\
\text { is engine } \\
\text { observe the } \\
\text { things like } \\
\text { sensors by } \\
\text { considering } \\
\text { a used item }\end{array}$ & $\begin{array}{c}\text { It } \\
\text { increases } \\
\text { stability } \\
\text { in the } \\
\text { system }\end{array}$ & $\begin{array}{l}\text { It has security } \\
\text { issues. }\end{array}$ & N/A \\
\hline$\# 11$ & $\begin{array}{l}\text { This paper is } \\
\text { based on a } \\
\text { recommendation } \\
\text { system for brown } \\
\text { planthopper } \\
\text { control }\end{array}$ & $\begin{array}{c}\text { IoT, } \\
\text { multiscaling, }\end{array}$ & $\begin{array}{c}\text { It } \\
\text { decreases } \\
\text { the bph rate } \\
\text { in the } \\
\text { problem. }\end{array}$ & $\begin{array}{c}\text { It } \\
\text { decreases } \\
\text { the } \\
\text { growth } \\
\text { rate of the } \\
\text { bph }\end{array}$ & $\begin{array}{c}\text { Battery } \\
\text { consumption will be } \\
\text { more and more } \\
\text { sensors can be used } \\
\text { for the way of farmers. }\end{array}$ & $\begin{array}{c}\text { We can } \\
\text { increase the } \\
\text { measures to } \\
\text { decrease the bph } \\
\text { rate. }\end{array}$ \\
\hline$\# 12$ & $\begin{array}{l}\text { This paper is } \\
\text { based on the } \\
\text { application and } \\
\text { improvement of } \\
\text { intelligence } \\
\text { recommendation } \\
\text { of agriculture } \\
\text { information }\end{array}$ & $\begin{array}{l}\text { IoT, the prior } \\
\text { algorithm }\end{array}$ & $\begin{array}{c}\text { The } \\
\text { sensors and } \\
\text { Raspberry } \\
\text { PI were } \\
\text { interfaced } \\
\text { and wireless } \\
\text { communica } \\
\text { tion was } \\
\text { established } \\
\text { using IoT. }\end{array}$ & $\begin{array}{c}\text { It } \\
\text { increased } \\
\text { the } \\
\text { improvem } \\
\text { ent in } \\
\text { informati } \\
\text { on for } \\
\text { agricultur } \\
\text { e }\end{array}$ & $\begin{array}{l}\text { The power supply } \\
\text { is a disadvantage. As } \\
\text { the entire system fails } \\
\text { without power supply, } \\
\text { it can be a } \\
\text { disadvantage. Images } \\
\text { captured during the } \\
\text { day may be affected } \\
\text { due to excess sunlight } \\
\text { and images cannot be } \\
\text { clicked clearly at } \\
\text { night. }\end{array}$ & N/A \\
\hline
\end{tabular}

\section{CONCLUSION}

Everywhere we talk about making India Smart from our homes to cities in our states, but in all this, we forget about our country's backbone i.e. Our Indian Agriculture. India ranks second in the farm output worldwide. The agricultural sector, in fact, is the most important sector in the country. As per the statistics of 2013, India accounted for $13.7 \%$ of the gross domestic product, but over time, the results are declining. There are several ideas which are executed and a few are yet to be implemented. By reading different papers on Smart Agriculture, we came to the conclusion that our Indian agriculture needs to be changed and made smart by using different technologies such as IoT, Artificial Intelligence, Cloud Computing and Big Data combined together. IoT can be used to automate the equipment, thereby minimizing the human effort. It also can be used to analyze the data collected by the sensors present in the field. Drones used to monitor the entire field easily and capture the images of plants regularly at a certain time makes use of Artificial Intelligence. The data gets recorded every single second by the sensors and Big Data helps us to collect this huge amount of data. We can also retrieve past data from it and analyze for the present and also the future. Since the data amount is huge, its storage problem can be solved using cloud computing. There are a few problems even in the existing implementation. Our plan is to introduce a system which will not only solve those existing problems but will prove to be a unique feature to tackle other new problems as well. Adding to the future scope of the paper, we are integrating our idea with Machine Learning to predict the demand and supply problem which predicts the market rate at the time of harvesting. The model predicts the price and crop to be grown which provides profit to the farmers. Overall, by combining all these technologies we can make our Indian Agriculture as Smart Agriculture.

\section{ACKNOWLEDGMENTS}

The manuscript is prepared by taking assistance from Accendere Knowledge Management Services Pvt. Ltd, we are thankful to them. We also express our gratitude to our teachers and mentors for guiding us throughout the work 


\section{REFERENCES}

1. S. Kanaga Suba Raja, R. Rishi, E. Sundaresan, and V. Srijith, "Demand Based Crop Recommender System For Farmers," in 2017 IEEE International Conference on Technological Innovations in ICT For Agriculture and Rural Development (TIAR 2017), 2017, pp. 194-195.

2. M. J. Mokarrama and M. S. Arefin, "RSF: A recommendation system for farmers," in 5th IEEE Region 10 Humanitarian Technology Conference 2017, R10-HTC 2017, 2017, pp. 843-850.

3. S. Pudumalar, E. Ramanujam, R. H. Rajashree, C. Kavya, T. Kiruthika, and J. Nisha, "Crop recommendation system for precision agriculture," in 2016 8th International Conference on Advanced Computing, ICoAC 2016, 2016, pp. 32-36

4. C. Shampa and M. Aseem, "IoT based Weather and Location Aware Recommender System," in 2018 8th International Conference on Cloud Computing, Data Science \& Engineering (Confluence), 2018, pp. 610-617.N. Navya Sri, “A Graph-based Trust-enhanced Recommender System for Service Selection in IOT," in International Conference on Inventive Systems and Control (ICISC-2017), 2017, pp. 1-5.

5. T. Okayasu et al., "Affordable field environmental monitoring and plant growth measurement system for smart agriculture," in Proceedings of the International Conference on Sensing Technology, ICST, 2017, pp. 1-4.

6. Y. Zhao and S. H. Bai, "Research on optimizing recommend system for agriculture information personalization based on user clustering," in Proceedings of the 2012 International Conference on Industrial Control and Electronics Engineering, ICICEE 2012, 2012, pp. 1477-1480.

7. Y. Lai and J. Zeng, "A cross-language personalized recommendation model in digital libraries," Electron. Libr., vol. 31, no. 3, pp. 264-277, 2013.

8. Z. Ren and X. Lu, "Design of fertilization recommendation knowledge base and appllication," in 2012 1st International Conference on Agro-Geoinformatics, Agro-Geoinformatics 2012, 2012, pp. 203-207.

9. V. P. M S Mekala, "A Novel Technology for Smart Agriculture Based on IoT with Cloud Computing," in International conference on I-SMAC (IoT in Social, Mobile, Analytics and Cloud) (I-SMAC 2017), 2017, pp. 75-82.

10. N. Vinh Gia Nhi, D. Alexis, and H. Hiep Xuan, "Toward an agent-based multi-scale recommendation system for Brown plant hopper control," in Proceedings - UKSim-AMSS 6th European Modelling Symposium, EMS 2012, 2012, pp. 9-14.

11. Y. Feng, Z. Qian, L. Rupeng, Z. Junfeng, and L. Xin, "Application and improvement of intelligent recommendation for Agricultural Information," in Proceedings - International Conference on Natural Computation, 2013, pp. 1077-1081. 